\title{
Teacher Candidates' Assessment for Pedagogy Education: Karabuk University/Turkey Sample ${ }^{i}$
}

\author{
Ömer Aydoğdu ${ }^{*}$, Nurhayat Çelebi \\ Department of Education, Faculty of Letters, Karabuk University, Turkey
}

Copyright $\bigcirc 2017$ by authors, all rights reserved. Authors agree that this article remains permanently open access under the terms of the Creative Commons Attribution License 4.0 International License

\begin{abstract}
The aim of this research is to determine the extent of benefit of teacher training education of the teacher candidate students who are having pedagogical teacher training education. This research is a quantitative study in general screening model. In the research, a questionnaire formed of 5-point Likert type with 26 items was used. Cronbach Alpha coefficient of the scale was 0,74. 222 teacher candidates participated into the study. The scale items were gathered under sub-dimensions of 'lessons taken by means of distant education, lessons taken by means of face-to-face education, teaching practice process in schools and general assessment of teacher training education'. According to the findings of the research, it was seen that assessments of the teacher candidates relating to the profession were positive. The students preferred face-to-face education to on-line education. Within this process, the importance of teaching practice was detected due to the provision of opportunity for the candidates for putting their theoretical knowledge into practice. No significant difference was seen in the assessments of the teacher training education in terms of gender by the teacher candidates. There was a difference in sub-dimension of 'lessons taken by means of face-to-face education' with respect to the group of History-Geography students. As suggestions, it is anticipated that teacher training education of the teacher candidates should be provided with the face-to-face education freely and courses should be arranged within four years of undergraduate education programs.
\end{abstract}

Keywords Teacher Candidates, Teacher Training Education, Practice Schools

\section{Introduction}

Teaching practices have an extensive and important stage in programs oriented towards teaching training in Turkey. Regulations relating to teacher training were initiated with proclamation of the republic. Researches in this field are still continuing today. In Basic Education Law numbered 1739 in Turkey, it is stated that "Teaching is a special professional undertaking education and related management tasks of government. Teachers need to conduct their tasks in accordance with the Turkish National Education purposes and basic principles. Teacher training is involved with general culture, special field education and pedagogical education (National Education Basic Law, 1973). The most extensive studies relating to teacher training in Turkey were handled with the instruction numbered 1998/2493. Among the principles of that instruction, the time to be spent in practice schools by teacher candidates was increased; the school experience and the teaching practice courses relating to teaching profession practices were incorporated into the teaching programs. According to 1998 Ministry of National Education (MNE) legislation, “... aims, principles and methods of teaching practice applications to be conducted in the state and the private education institutions in affiliation with Ministry of National Education Program' are arranged. In this legislation, the teaching practice is defined as a course or a learning process which provides teacher candidates how to teach in their field, and the seventh item of this is related to the period of teaching practices. It is stated in that "Teaching practice in undergraduate and postgraduate-level teacher training programs is conducted for at least a semester as a whole or as two half-times in a week in the last semester. Each teacher candidate has to be in teaching applications for at least 24 hours of this period in person. As it is being programmed, the capacity of practice schools should be considered and the total of teacher candidates be determined before the teacher candidates being directed to the schools. They may be divided into two groups and the teaching practices may be continued for both semesters" (MNE, 1998). The most extensive change after 1998 was performed with decision of the Board of Education Department in the Ministry of National Education, dated 20 February 2014 and numbered 09 . The third section of this change comprises the units responsible for conducting the program, course programs and other details (The 
Council of Higher Education Board, 2014). Accordingly, as stated in the fourth section of the Journal of Notifications numbered 1998/2493 of MNE, “...teacher training process is based on the determination of teacher candidate groups, the roles of the university coordinators, and the school coordinators, the school mentors and the details of how the whole program should be organized.' The principles and the instructions of this legislation might have been applied slightly different in different universities in the past. However, the final form of it which has to be obeyed was announced by the Ministry of National Education Teacher Training and Development Department, dated 23.01.2017, and was sent to all City National Education Directorates and the universities (MNE, 2017). According to that, each university coordinator and the school mentors cannot conduct more than three teacher candidate groups, and not more than six candidates can take part in each group. This restriction affects the process negatively as there are not enough field-expert lecturers in the universities. Yet it can be thought that it is better than the previous application because it gives the chance of being in conformity with the teacher training studies. The university and the Ministry of Education have been in a good coordination in the evaluation and the supervision processes of the candidates.

European Council Ministers of Education (2014) highlighted the necessity of the teacher training practice education. It was also emphasized that teacher candidates' education process at the universities before they were sent to the practice schools was an important stage for the teachers. They should be provided with the modern teaching skills abilities, and should be taught the knowledge of innovation and future. It was also suggested that encouragements to increase motivation in teaching career should be enabled, basic competences for a high-quality education should be provided and core programs for this purpose should be prepared (Celebi 2016:163). Teacher education and teaching practice courses may vary depending on the countries. For example, in France from EU countries, teacher candidates need to participate into 22 weeks of school experience in addition to 3 years of undergraduate education. In addition, all teacher candidates need to practice for three weeks in an industrial or commercial company so that they shall know what the economy and the its application in the companies is, and be able to transfer those experiences to their students in the schools. In Germany, teacher education is totally 6 years, as mainly 3 or 4 years of theory and 2 years of practice. In England, undergraduate education is generally conducted with 3 - or 4 year-programs. Field courses, education courses and teaching practice as essential for undergraduate education are conducted simultaneously. Apart from this practice, a process similar to the present practices in Turkey comprising a certificate program providing 1-year education courses and teaching practice in addition to 3-year program (Abazoğlu, 2014;
Çelebi, 2016; Şahin, 2015). As teacher training programs in USA vary from state to state, there is a requirement to have an undergraduate education of 4 years. Those who want to be teachers are accepted into the faculty of letters. From the third year, they have to take courses of 45 credits which are pre-requisite courses of the faculty of letters. Courses in the fourth year are practice-focused. In Finland, postgraduate level of education is necessary for being a teacher in all fields. Theory and practice integrity is highly important in teacher training system. In Japan, those who want to be teachers should go through 4 years of undergraduate education. Afterwards, teacher candidates are subjected to an academic skill test, a private field success measurement test and a number of selection exams consisting of school portfolio files examinations (Demirel, 2000).

In Turkey, teacher training process is realized in two separate ways. First, those who graduated from the Faculty of Education having with BAED diploma, those graduates can be appointed to the schools as teachers if they can be successful in the written and oral examinations given by the Ministry of Education (MNE). Second, the ones who graduated from the various departments of the Faculty of Science and letters, they are either BA degree diploma or the BSc diploma holders. However, they have to take one year pedagogy education as an addition to their $\mathrm{Ba}$ and $\mathrm{BSc}$ education. In addition, they have to be successful in written and oral examinations given by the MNE. This study was conducted for determining the educational attainments of teacher candidates in the theoretical and practical contribution of the teacher training education in the faculty of sciences and letters in the universities. And the following questions have been determined as the sub-problems of the research:

\section{Sub-problems}

1. What are the opinions of the teacher candidates relating to distant education?

2. What are the opinions of the teacher candidates relating to face-to-face education?

3. What are the opinions of the teacher candidates relating to teaching practice process in schools?

4. What are the general assessments of teacher candidates relating to the teaching practice process in schools?

5. Is there any difference in the opinions of the teacher candidates relating to the teaching practice in terms of gender?

6. Is there any difference in the opinions of the teacher candidates relating to the teaching practice in terms of their branches?

Method: The study is a quantitative descriptive survey model. This research model is a research approach aiming to describe a situation in the past or present as it is. The 
event, individual or object of the study is defined as it is within its own conditions (Karasar, 2005).

Population and Sampling: The population of the study consists of 420 teacher candidates and the working population consists of 222 teacher candidates participating into the teacher training education certificate program in Karabuk University/Turkey in 2016-2017 Education Session. An additional sample receiving method was not applied. The questionnaire forms which have to be filled in by the teacher candidates were distributed first and then collected with the efficient coordination of the heads of departments in the faculties and the coordinator teachers in the practice schools. From 232 questionnaires that were returned, 10 questionnaires were not incorporated into assessment. The number of valid questionnaires was 222 .

Data Collection Tools: In this study conducted for assessing the teaching practice, a measurement tool of 26 items was used. The scale items were developed by the researchers, and the validity of items was enabled by taking 5 expert opinions in the field. Cronbach Alpha reliability coefficient of the questionnaire was 0,74. The questionnaire was based on gender, age and department as demographical variables. The scale was prepared in 5-point Likert type. Answers for each question were graded between 1.00 and 5.00 as in 5-point Likert type scales. Accordingly, point intervals were as follows: 1.00-1.79 totally disagrees; $1.80-2.59$ disagree; $2.60-3.39$; partially agree, 3.40- 4.19 agree; $4.20-5.00$ totally agree. Negative statements in the scale were assessed in reverse. The scale items were collected under six sub-dimensions, but they can shortly be grouped into four sub-dimensions. The first one comprises opinions relating to the distant education; the second one comprises opinions relating to the face-to-face education; the third one is about the teaching practice process and the fourth one comprises the general assessment of the teacher training education as a whole.

Analysis Techniques: SPSS 22.0 package program (The Statistical Packet for Social Sciences) was used in analysis of the data. Levene's Test for Equality of Variances was used to determine whether the distribution was homogenous. It was detected that variances were homogenous. T-test was applied to determine the differences between teacher training practices in terms of genders, and one-way ANOVA test was applied to test the differences among the teacher training practices in terms of the branches of the participants. Moreover, as there were no age differences among the teacher candidates, no statistical procedure was realized.

Findings: Personal preferences of the teacher candidates and the information relating to the study variables are given below. According to personal information, 69,4\% (154) of the teacher candidates were females and $30,6 \%(68)$ were males. $81,12 \%(180)$ of the participants were 25 years old and $18,9 \%(42)$ were 26 years old. In terms of their branches, $24,8 \%$ (55) were students of Health-Mathematics, $45,9 \%$ (102) of History-Geography and $29,3 \%$ (65) of English-Turkish Language and Literature departments.

\section{Opinions of Teacher Candidates relating to Teacher Training Education:}

Table 1. Opinions of the teacher candidates relating to distant education

\begin{tabular}{llcc}
\hline & Distant education... & $\overline{\mathrm{X}}$ & $S d$ \\
\hline 1. & Has contributed to teaching practice process by means of Class Management course. & 3.50 & 1.07 \\
2. & Has contributed to teaching practice process by means of Program Development in Education course. & 3.34 & 1.01 \\
3. & Has contributed to teaching practice process by means of Measurement and Assessment course. & 3.30 & 1.18 \\
4. & Has contributed to teaching practice process by means of Education Psychology course. & 3.45 & 1.07 \\
5. & Has contributed to teaching practice process by means of Introduction to Education course. & 3.55 & 1.03 \\
6. & Has contributed to teaching practice process by means of Turkish Education History course. & 3.26 & 1.14 \\
7. & Has contributed to teaching practice process by means of Teaching Principles and Methods course. & 3.40 & 1.14 \\
\hline & & Total & 3.39 \\
\hline
\end{tabular}

$\mathrm{N}=222$

According to Table 1, the teacher candidates stated that they mostly acquired benefit from Introduction to Education $(\bar{X}=3.55)$ and Class Management $(\bar{X}=3.50)$ courses during the theoretical training period that they had as a distant education. The courses that they acquired the least benefit were Turkish Education History $(\bar{X}=3.26)$ and the result about the Measurement and Assessment course is $(\overline{\mathrm{X}}=3.30)$. It was understood that they acquired intermediate level of benefit from other courses.

Table 2. Opinions of the teacher candidates relating to face-to-face education

\begin{tabular}{llcc}
\hline & Face-to-face Education... & $\overline{\mathrm{X}}$ & Sd \\
\hline 1. & Has contributed to teaching practice process by means of Teaching Technologies and Material Development course. & 4.14 & 1.02 \\
\hline 2. & Has contributed to teaching practice process by means of Special Teaching Methods course. & 4.15 & 0.98 \\
\hline 3. & Has provided me with high-level of gains relating to learning-teaching processes. & 4.05 & 0.97 \\
\hline & Total & 4.09 & 0.67 \\
\hline
\end{tabular}


According to Table 2, it was seen that the teacher candidates acquired a great amount of benefit from Teaching Technologies and Material Development $(\overline{\mathrm{X}}=4.14)$ course and Special Teaching Methods $(\overline{\mathrm{X}}=4.15)$ course that they had by means of the face-to-face education. As a result it may be said that the face-to-face education was more efficient in terms of the students' preferences.

Table 3. Opinions of the teacher candidates relating to teaching practice in schools

\begin{tabular}{|c|c|c|c|}
\hline \multicolumn{2}{|r|}{ During Teaching Practice Process... } & \multirow{2}{*}{$\frac{\bar{X}}{3.10}$} & \multirow{2}{*}{$\begin{array}{c}S d \\
1.21\end{array}$} \\
\hline 1. & I have learned preparing the lesson plans from the university coordinator lecturers. & & \\
\hline 2. & I have learned preparing lesson plans from guiding branch teachers in the schools. & 3.19 & 1.21 \\
\hline 3. & I have learned preparing lesson plans from the plan samples in the website of the MNE. & 3.11 & 1.16 \\
\hline 4. & I have not associated courses that I taught and courses that I had in university education & 3.21 & 1.12 \\
\hline 5. & I have had difficulty in lecturing as courses that I taught and courses that I had in university education were not associated & 3.46 & 1.17 \\
\hline 6. & I have had difficulty in using class materials such as smart board provided by school while teaching. & 3.50 & 1.22 \\
\hline 7. & I have not been able to prepare material relating to the course while teaching & 3.89 & 1.11 \\
\hline 8. & I have not been able to apply my course plan during the anticipated time while teaching & 3.78 & 1.08 \\
\hline 9. & I have not been able to apply modern methods that I have learned theoretically during course. & 3.68 & 1.08 \\
\hline & Total & 3.39 & 0.89 \\
\hline
\end{tabular}

$\mathrm{N}=222$

According to Table 3, while preparing the lesson plans, the teacher candidates mostly acquired benefit from practice teachers $(\bar{X}=3.19)$. It was seen that they acquired almost equal benefit from the lecturers of the related courses $(\bar{X}=3.10)$, and from the ready modular plan samples in the website of the Ministry of National Education $(\overline{\mathrm{X}}=3.11)$. Teacher candidates stated that they could not prepare course materials $(\bar{X}=3.89)$, and they could not direct the anticipated lesson time for each class efficiently $(\bar{X}=3.78)$, and that they could not apply the modern teaching methods $(\bar{X}=3.68)$ while teaching.

Table 4. General assessment of the teacher candidates relating to teaching practice in schools

\begin{tabular}{|c|c|c|c|}
\hline & General Assessment of the Teacher Training by the Candidates & $\bar{X}$ & $S d$ \\
\hline 1. & I have not received sufficient education for designing and developing the teaching materials during the university education & 3.42 & 1.08 \\
\hline 2. & I do not think that the exams of each course of the teacher training program are trustworthy & 3.42 & 1.14 \\
\hline 3. & $\begin{array}{l}\text { Contents of courses provided as the theoretical education at the university are not matching with those of National Education } \\
\text { Curriculum Program in use at schools. }\end{array}$ & 3.36 & 1.08 \\
\hline 4. & $\begin{array}{l}\text { I would have been more successful if I had taken all courses on teacher training education program as face-to-face instead of taking } \\
\text { them mostly on line }\end{array}$ & 4.05 & 0,96 \\
\hline 5. & If the teacher training education is continued as it is now, it may damage the social equality rights among the citizens. & 4.05 & 1.00 \\
\hline 6. & Teacher training education courses should be provided within the university undergraduate program as distributed to the four years & 3.91 & 1.16 \\
\hline 7. & I suppose that the teacher training education process in the science and letters faculties is unnecessary & 2.76 & 1.30 \\
\hline & Total & 3.56 & 0.51 \\
\hline
\end{tabular}

$\mathrm{N}=222$

According to Table 4, teacher candidates thought that they would be more successful if the teacher training education was provided as the face-to-face education $(\overline{\mathrm{X}}=4.05)$. They also mentioned that the present application of teacher training process at the Science and Letters Faculties might damage the social equality rights among the citizens $(\overline{\mathrm{X}}=4.05)$. The lowest participation was for the statement "I suppose the teacher training education process in the Science and Letters Faculties is unnecessary" $(\overline{\mathrm{X}}=2.76)$. 


\section{Analysis of Differences of Teacher Candidates in Terms of Independent Variables}

\section{T-test Results}

Table 5. t-test results of the teachers for distant education, face-to-face education, teaching practice and general assessment dimensions in terms of their genders

\begin{tabular}{|c|c|c|c|c|c|c|}
\hline Dimensions & Gender & $N$ & $\bar{X}$ & Sd. & $S d$ & $t$ \\
\hline \multirow{2}{*}{ Distant education } & Female & 154 & 3.36 & .92 & 120 & \multirow{2}{*}{.871} \\
\hline & Male & 68 & 3.47 & .86 & & \\
\hline \multirow{2}{*}{ Face-to-face Education } & Female & 154 & 4.08 & .65 & 120 & \multirow{2}{*}{-1.08} \\
\hline & Male & 68 & 4.19 & .76 & & \\
\hline \multirow{2}{*}{ Teaching Practice } & Female & 154 & 3.43 & .60 & 120 & \multirow{2}{*}{-1.11} \\
\hline & Male & 68 & 3.44 & .61 & & \\
\hline \multirow{2}{*}{ General Assessment } & Female & 154 & 3.55 & .52 & 120 & \multirow{2}{*}{-.381} \\
\hline & Male & 68 & 3.58 & .48 & & \\
\hline
\end{tabular}

$\mathrm{p}>.05$

In Table 5, there was no significant difference detected between distant education, face-to-face education, teaching practice and general assessment and general assessment dimensions in terms of gender variable $(\mathrm{p}>.05)$.

Table 6. One-way ANOVA test results relating to distant education, face-to-face education, teaching practice and general assessment dimensions in terms of branches of the teacher candidates

\begin{tabular}{|c|c|c|c|c|c|c|c|c|}
\hline Dimensions & Branch & $N$ & $\bar{X}$ & $S d$. & $S d$ & $F$ & $\boldsymbol{P}$ & Difference \\
\hline \multirow{4}{*}{ Distant education } & Health-Mathematics & 55 & 3.34 & .889 & 2 & \multirow{4}{*}{.545} & \multirow{4}{*}{.580} & \\
\hline & History-Geo & 102 & 3.36 & .887 & 219 & & & \\
\hline & English-Turkish Language & 65 & 3.49 & .111 & 221 & & & \\
\hline & Total & 222 & 3.39 & .059 & & & & \\
\hline \multirow{4}{*}{ Face-to-face Education } & Health-Mathematics & 55 & 4.03 & .697 & 2 & \multirow{4}{*}{5.69} & \multirow{4}{*}{$.004 *$} & \multirow{4}{*}{$2-3$} \\
\hline & History-Geo & 102 & 4.27 & .634 & 219 & & & \\
\hline & English-Turkish Language & 65 & 3.93 & .726 & 221 & & & \\
\hline & Total & 222 & 4.11 & .692 & & & & \\
\hline \multirow{3}{*}{ Practice } & Health-Mathematics & 55 & 3.42 & .520 & 2 & \multirow{3}{*}{.837} & \multirow{3}{*}{.434} & \\
\hline & History-Geo & 102 & 3.48 & .618 & 219 & & & \\
\hline & Total & 222 & 3.43 & .608 & & & & \\
\hline \multirow{4}{*}{ Assessment } & Health-Mathematics & 42 & 3.52 & .497 & 2 & \multirow{4}{*}{.242} & \multirow{4}{*}{.785} & \\
\hline & History-Geo & 102 & 3.57 & .555 & 219 & & & \\
\hline & English-Turkish Language & 65 & 3.59 & .458 & 221 & & & \\
\hline & Total & 222 & 3.56 & .513 & & & & \\
\hline
\end{tabular}

$P<.05$

In Table 6, according to the results of one-way ANOVA, there was a significant difference between the group of History-Geography branch students, and the group of English Language Literature and Turkish Language Literature students in "face-to-face education" dimension. According to Scheffe, this difference was caused by the group of History-Geography branch students. History-Geography students $(\overline{\mathrm{X}}=4.27)$ considered that face-to-face education was more beneficial than the distant education compared to English Language Literature and
Turkish Language Literature students $(\overline{\mathrm{X}}=3.93)$.

Results, Conclusion and Recommendation: According to the results of this study, teacher candidates thought that distant education practice provided them with great amount of contribution during the teacher training education process. However, they have clarified that it would have been more beneficial for them if the whole program had been given them as in the face to face education system. As a result of that point, it has been determined that their preferences on teaching technologies 
and material development course and the course on special education teaching methods that they had taken in face-to-face education system is on the top range among the others in the questionnaire. Because these courses are type of requiring direct communication and practice with students, the teacher candidates prefer this interactive learning technique over online learning system. It was stated in İşman's study that all students using the information technologies had a high-level stimulation towards learning (İşman, 2011:211). In the study of Karataş constituting experiment and control groups, students were more successful in face-to-face education (Karataş, 2006:113-132). Opinions of the teacher candidates relating to teaching practice process in schools were generally positive. In the process, it was stated that mentors in schools were the most beneficial for students about the preparation of lesson plans. In addition, the candidates mentioned that they could not develop the required course materials while teaching, that they could not complete the course within the required time, that they could not apply modern methods and that they could not exhibit the skill of using smart board. They expressed that they were in difficulties of matching the contents of courses they had been taught at the university with the contents of the classes in the practice school curriculum, which was the program of the Ministry of National Education.

The candidates believe that they can be more successful if they have taken all courses as the face-to-face education. In addition, the candidates stated that the courses of teacher training education program should be provided within four years of undergraduate education process by distributing the courses of the program over eight semesters. There was no significant difference detected between the gender variable of the teacher candidates. There was a significant difference detected in face-to-face education dimension in terms of branches. This difference was between the groups of History-Geography branches, and the group of English Language and Literature-Turkish Language Literature branches. The teacher candidates of History-Geography branches preferred face-to-face education more than the teacher candidates of English Language and Literature-Turkish Language Literature branches.

In the study of S1lay and Gök (2004), half of teacher candidates stated that teaching practice process in schools was highly beneficial; they utilized aid from guiding practice teachers for solution of problems encountered in practice school, however, there were some problems experienced within scope of faculty-school collaboration (S1lay and Gök, 2004: 6-8). Eraslan (2009) stated that the candidates acquired benefit during the practice from teaching profession courses; they actually felt like teacher of a class; and they acquired the opportunity to know school/class environment and students closely. Paker (2008), Kırksekiz, İşbulan, Akgün, Kıyıcı, Horzum (2015) stated in their studies that teacher candidates could not acquire sufficient benefit from the lecturers assigned by the university and the guiding branch teachers in schools. Becit, Kurt and Kabakçı (2009) had the opinion in their study that school practice courses were beneficial in teaching education. They expressed that teacher candidates saw their shortcomings and they gained experience by overcoming their anxiety (Becit, Kurt and Kabakçı, 2009: 169-184). Aytunga (t.y) indicated that school experience courses had a positive effect on teacher candidates. Özmen stated in his study (2008) that the candidates could not receive enough feedback for their reports from the lecturers and the guiding school teachers. In the study of Ören, Sevinç and Erdoğmuş (2009), it was determined that teacher candidates had positive attitudes relating to school experience 1-2 courses. No significant difference was found in attitudes of the teacher candidates towards the profession in terms of gender. The result of Oren and colleagues' study supports our study on this point. In another study, there was no significant difference in terms of departments, while there was a differentiation between two different departments in our study.

Recommendations: According to the findings of this study, the following suggestions can be recommended for redesigning the teacher training program more effectively and developing the teaching practice process more efficiently:

- As stated in study results, the coordination among the faculties, ministry of education directories in cities and school administrations should be rendered more efficiently.

- Guiding branch teachers to be assigned in practice schools should be selected among the experienced ones, and should be the ones performing their guiding process eagerly.

- The teacher candidates should be educated about the usage of smart board in the technology classes at the university. The content of the Fatih Program in the smart board and the application of each lesson should be taught to the candidates by the branch teachers in advance. It can be done during the observation stage of the teacher training practice process before they begin to teach in the classroom actively.

- Teacher training education courses should be provided within four years of undergraduate education process, and it should no longer be paid.

\section{REFERENCES}

[1] Abazoğlu, İ (2014). Dünyada öğretmen yetiştirme programları ve öğretmenlere yönelik mesleki gelişim uygulamalar1. Turkish Studies, 9(5), 1-46.

[2] Çelebi,N.( 2016).Avrupa Birliği ve eğitim. Küreselleşme ve eğitime yansımaları .Edit.N.Çelebi. Nobel Ankara. 
[3] Eraslan,A(2009). İlköğretim matematik öğretmen adaylarının öğretmenlik uygulaması üzerine görüşleri. Necatibey Eğitim Fakültesi Elektronik Fen ve Matematik Ĕ̌itimi Dergisi(EFMED), 3(1) Haziran 2009, 207-221.

[4] Eurydice (2007). Retrieved from http://www.eurydice .org

[5] Becit, G., Kurt, A. A., Kabakçı,I. (2009). Bilgisayar öğretmen adaylarının okul uygulama derslerinin yararlarına ilişkin görüşleri. Anadolu Üniversitesi Sosyal Bilimler Dergisi. Anadolu University Journal of Soctal Sclences, 9(1), 169-184.

[6] Göktaş, Ö.; Şad,S.N.(2014). Okul deneyimi ve öğretmenlik uygulaması dersi uygulama öğretmenlerinin seçim süreci: ölçütler, sorunlar ve öneriler. Hacettepe Üniversitesi Ĕgitim Fakültesi Dergisi (H. U. Journal of Education) 29(4), 115-128. Ekim 2014

[7] Demirel,Ö.(2000). Karşılaştırımalı eğitim. Ankara: PegemA.

[8] Karasar,N.(2005).Bilimsel araștırma yöntemi kavramlar-ilkeler-teknikler. Ankara: Nobel.

[9] Karataş,S. (2006).Deneyim eşitliğine dayalı internet temelli ve yüz yüze öğrenme sistemlerinin öğrenci başarıs açısından karşılaştırılması. Gazi Eğitim Fakültesi Dergisi, 26(3), 113-132.

[10] METK (1973). Milli Eğitim temel kanunu. Kanun numarası: 1739, Kanun Tarihi: 14/06/1973.

[11] MEB (1998). Milli eğitim bakanlığına bağlı eğitim öğretim kurumlarında yapacakları öğretmenlik uygulamasına ilişkin yönerge. Tebliğler Dergisi. Ekim1998/2493, Cilt: 61.

[12] MEB (Milli Eğitim Bakanlığı), (2008). Öğretmenlik yeterlilikleri. MEB. Yayını. Ankara. Program ve içerik bilgisi.

[13] MEB (1995). MEB. Aday öğretmenlerin yetiştirilmesine ilişkin yönetmelik.14.07.2017 tarihinde http://mevzuat. meb.gov.tr adresinden alınmıştır.

[14] Ören, F.Ş.; Sevinç, Ö.S.; Erdoğmuş, E. (2009). Öğretmen

Thank you very much to the rectorate of Karabuk University because they supported us financially on this Project presented in the conferance organized by ICLEL 2017 in Porto/Portugal. adaylarının okul deneyimi derslerinin ve tutumlarının değerlendirilmesi. Kuram ve Uygulamada Ĕ̌itim Yönetimi.15 (58), 217-246.

[15] Özmen, H. (2008). Okul deneyimi -1 okul deneyimi-2 derslerine ilişkin öğretmen adaylarının görüşleri. On Dokuz Mayıs Üniversitesi Eğitim Fakültesi Dergisi.25, 25-37),

[16] Paker, T. (2008). Öğretmenlik uygulamasında öğretmen adaylarının uygulama öğretmeni ve uygulama öğretim elemanının yönlendirmesiyle ilgili karșılaștıkları sorunlar. 1 . Pamukkale Üniversitesi Ĕ̈itim Fakültesi Dergisi. Yıl 2008, 1(23). 132-139.

[17] Sılay, İ. ve Gök, T. (2004). Öğretmen adaylarının uygulama okullarında karşılaştıkları sorunlar ve bu sorunları gidermek amaciyla hazırlanan öneriler üzerine bir çalışma. XIII Ulusal Eğitim Bilimleri Kurultayı, 6-9 Temmuz 2004, İп̈nü Üniversitesi, Eğitim Fakültesi, Malatya.

[18] Şahin,D.(2015). ABD,Almanya,Fransa ve İngiltere'de Öğretmen Yetiştirilmesi. 14.07.2017 tarihinde https://prezi.com/h.../abdalmanyafransa-ve-ingilterede-ogr etmen-yetistirilmesi-Erișim adresinden alınmıștır.

[19] YÖK/ Dünya Bankas1, (1998). Milli eğitimi geliştirme projesi hizmet öncesi ögretmen eğitimi, Ankara.

[20] YÖK (1999). Aday öğretmen kılavuzu. Ankara: YÖK/Dünya Bankası Yayınları.

[21] YÖK (1997). Okullarda uygulama çalışmaları-Orta öğretim. YÖK/Dünya Bankası Milli Ĕgitim Geliştirme Projesi Hizmet Öncesi Öğretmen Ĕ̌̆itimi. Ankara.

[22] YÖK (1998). Fakülte-okul işbirliği. Ankara: YÖK/ Dünya Bankası Yayınları.

[23] Uslu, Z. (2001). Okul deneyimi derslerinin öğretmen adaylarına etkileri. Çăgdaş Ĕ̈itim, 282 (35-39)

[24] Kırksekiz, A.; İşbulan, O., Akgün, O.E.; Kıyıc1,M.; Horzum, M.B. (2015).Okul deneyimi ve öğretmenlik uygulaması derslerine eleștirel bir bakıs: problemler, beklentiler ve çözüm önerileri. Bartın Üniversitesi Eğitim Fakültesi Dergisi, Cilt 4, Say1 2, s.433-451, Aralık 2015. 